\title{
Will Financial Analysts Mistake Stocks of Good Companies for Good Stocks? Evidence from Taiwan Stock Market
}

\author{
I-Ju Chen \\ The Department of Finances, National Taiwan University, Taiwan
}

\begin{abstract}
It has been shown that the individual or institutional investors rely on the information provided by the financial analysts. A good stock recommended by financial experts is expected to make profit to the investors. However, due to the cognitive biases, the financial analysts or investors are probably confused in the firm characteristics between the good stocks and the stocks of good companies. Good companies are normally inferred to the company that have good managing and operating systems, however, it is usually though to have good returns as good stocks. The future earning forecasts of these good companies may be thus overestimated as compared with the others. Such cognitive biases probably results in improper investment and investment loss. In this study, the reputation survey results for the companies in Taiwan and the corresponding financial data are used to verify the proposed cognitive biases hypothesis. The empirical evidence in this study shows that financial analysts mistake stocks of good companies for good stocks. However, it is also shown that the average one-year buy-and-hold return of these sample firms (including good companies and good stocks) is still higher than that of the chosen matching firms.
\end{abstract}

Key words: Cognitive biases, financial analysts, expectations on stock return

\section{INTRODUCTION}

In many countries, high percentage of equity investments is traded by the institutional investors and they thus play a very important role in stabilizing the stock market. However, more than $80 \%$ of equity investments in Taiwan stock market are from the households. Since individual investors are less capable of analyzing the stock information, most of them utilize the security analysts' reports or institutional investor behavior as references to make investment decisions. The individual investors' behavior or stock price reaction is thus easily influenced by the information or recommendation provided by the security analysts, further causing the instability in the stock market. In addition, some institutions also use the recommendations for investment provided by security analysts as references to make equity investment decisions. The security analysts disseminate the information or trading recommendations to the individuals and institutions. Thus, the influence of security analysts on the stock market can not be neglected in the individual-oriented or institutional-oriented stock markets.

The influences of information provided by security analysts have been discussed in several studies [1,2]. [1] finds that security analysts tend to suggest "buy" rather than "sell" recommendations and there is a strong empirical evidence that stock prices are significantly influenced by the analysts' recommendation. [2] also argue that analysts may have biased or optimistic earnings forecasts for their career concerns. The behavior-based argument has been used to explain some anomalies in financial markets, such as the size effect [3] and the value effect $[4,5]$. In addition, the study [6] reveals that the survey respondents of Fortune magazine tent to have cognitive biases which have been discussed in the cognitive psychology literature and are proposed by the behavior finance. In addition, they argue that the superior performances of stocks of small companies or the stocks with high book-to-market ratios are due to the investor's cognitive biases.

Thus, it is important to understand whether financial analysts supply "unbiased" judgments to the public unintentionally resulting from the cognitive biases. If the analysts disseminate the biased recommendations unintentionally, it is also necessary to understand the influence of these biased recommendations. This study is thus aimed at understanding whether the cognitive biases exist among financial analysts. An investigation of the influence of the perception of analysts on stock returns is also carried out in this article.

\section{MATERIALS AND METHODS}

The primary data set from the annual survey of company reputations conducted by Common Wealth magazine in Taiwan from 1997 to 2002 is used in this study. Common Wealth magazine has published the annual survey of company reputations since 1994 . During the survey, more than 4,000 senior executives, outside directors and financial analysts are invited to evaluate 
ten large companies in their own industry category. A scale of one (poor) to ten (excellent) is used on ten attributes of reputation. These attributes include sense of vision (SV), innovativeness (IN), customer-orientedness (CO), operation performance, financial soundness, keeping talented people, technical applications, internationalization, long-term investment value (VLTI) and responsibility to the community. Normally the quality of company is ranked by the average score of the ten attributes. Thus, the equally weighted score of ten variables (AVG) is used as the proxy for a good company in this study.

$[6,7]$ have reported that the value of long-term investment (VLTI) is good for being a proxy as a good stock. Therefore, the value of a long-term investment is chosen to stand for the expectations about returns on the companies' stock. A high score of VLTI delegates the stocks with higher expectations about returns, which is normally considered as a good stock. Since the Common Wealth Magazine survey in 1997 started to use the value of long-term investment (VLTI) as one of the ten attributes, 1997-2003 survey results are used to investigate in this study.

The variables of firm characteristics used for the investigation include the systematic risk ( $\beta$ ), book-to-market ratio (BM), market equity (ME), cash flow to price $(\mathrm{C} / \mathrm{P})$, earning to price $(\mathrm{E} / \mathrm{P})$ and sales growth rate $(\mathrm{SG})$. The definitions of these variables are shown in Table 1. Normally these variables are calculated in the calendar year data. Since the annual survey of company reputations is announced and published in October, to ensure that the survey information is well spread and to study the influence of the survey on the financial analyst's recommendation and the stock return, the one-year lag stock return data and the corresponding systematic risk are used in this study. For example, the accounting data by the end of fiscal year in the calendar year $t$ (e.g. 1997) are analyzed with those of the next year $(t+1)$ stock returns and the corresponding systematic risk ( $\beta$ ) (e.g. 1998). A similar methodology has been reported in the study $[4,5]$.

The regression method is used to investigate the occurrence of cognitive biases among the financial experts in Taiwan stock market. The correlations of the firm characteristics with the stock of good companies and good stocks are respectively studied by using the following regression equations:

$$
\begin{aligned}
& A V G_{i, t}=a+b_{0} \beta+b_{1} M E_{i, t}+b_{2} B / M_{i, t}+b_{3} C / P_{i, t}+b_{4} S G_{i, t}+b_{5} P / E_{i, t}+\varepsilon_{i, t} \\
& V L T I_{i, t}=c+d_{0} \beta+d_{1} M E_{i, t}+d_{2} B / M_{i, t}+d_{3} C / P_{i, t}+d_{4} S G_{i, t}+d_{5} P / E_{i, t}+\varepsilon_{i, t}
\end{aligned}
$$

Table 1: $\quad$ The Definitions of Variables Used in the Study

\begin{tabular}{ll}
\hline Variables & Definitions \\
\hline Good Company (AVG) & Average score of the ten attributes (AVG) \\
Good Stock(VLTI) & Score on value of long-term investment \\
Beta $(\beta)$ & The coefficient estimates from CAPM model \\
Size $(\mathrm{ME})$ & Market equity at the end of each sample year \\
B/M & Book value of equity / market value of equity \\
Cash flow to price (C/P) & Net operation cash flow / market equity \\
Earning to price (E/P) & Net earnings / market equity \\
Sales growth rate (SG) & $\left(\right.$ Sales $_{\mathrm{t}}$-sales $\left._{\mathrm{t}-1}\right) /$ sales $_{\mathrm{t}-1}$ \\
\hline
\end{tabular}

Table 2: The Correlation of a Good Company (AVG as a Proxy) with the Various Firm Characteristics in the Fixed Effect

\begin{tabular}{|c|c|c|c|c|c|c|c|c|c|c|}
\hline & & Mode 1 & Mode 2 & Mode 3 & Mode 4 & Mode 5 & Mode 6 & Mode 7 & Mode 8 & Mode 9 \\
\hline constant & $\begin{array}{l}\text { coeff. } \\
\text { P. }\end{array}$ & $\begin{array}{l}-0.000 \\
(1.000)\end{array}$ & $\begin{array}{l}-0.000 \\
(1.000)\end{array}$ & $\begin{array}{l}-0.000 \\
(1.000)\end{array}$ & $\begin{array}{l}-0.000 \\
(1.000)\end{array}$ & $\begin{array}{l}-0.000 \\
(1.000)\end{array}$ & $\begin{array}{l}-0.000 \\
(1.000)\end{array}$ & $\begin{array}{l}-0.000 \\
(1.000)\end{array}$ & $\begin{array}{l}-0.000 \\
(1.000)\end{array}$ & $\begin{array}{l}-0.000 \\
(1.000)\end{array}$ \\
\hline$\beta$ & $\begin{array}{l}\text { coeff. } \\
\text { P. }\end{array}$ & $\begin{array}{l}-0.042 \\
(0.708)\end{array}$ & & & & & & $\begin{array}{l}0.003 \\
(0.981)\end{array}$ & $\begin{array}{l}0.001 \\
(0.990)\end{array}$ & $\begin{array}{l}0.017 \\
(0.872)\end{array}$ \\
\hline $\ln (\mathrm{B} / \mathrm{M})$ & $\begin{array}{l}\text { coeff. } \\
\text { P. }\end{array}$ & & $\begin{array}{l}-0.147 \\
(0.000)^{*}\end{array}$ & & & & & $\begin{array}{l}-0.067 \\
(0.133)\end{array}$ & $\begin{array}{l}-0.033 \\
(0.451)\end{array}$ & $\begin{array}{l}-0.041 \\
(0.362)\end{array}$ \\
\hline $\ln (\mathrm{ME})$ & $\begin{array}{l}\text { coeff. } \\
\text { P. }\end{array}$ & & & $\begin{array}{l}0.220 \\
(0.000)^{*}\end{array}$ & & & & $\begin{array}{l}0.174 \\
(0.002)^{*}\end{array}$ & $\begin{array}{l}0.178 \\
(0.001)^{*}\end{array}$ & $\begin{array}{l}0.177 \\
(0.001)^{*}\end{array}$ \\
\hline $\mathrm{C} / \mathrm{P}$ & $\begin{array}{l}\text { coeff. } \\
\text { P. }\end{array}$ & & & & $\begin{array}{l}0.051 \\
(0.744)\end{array}$ & & & & & $\begin{array}{l}0.127 \\
(0.388)\end{array}$ \\
\hline $\mathrm{E} / \mathrm{P}$ & $\begin{array}{l}\text { coeff. } \\
\text { P. }\end{array}$ & & & & & $\begin{array}{l}-0.0051 \\
(0.988)\end{array}$ & & & & $\begin{array}{l}-0.278 \\
(0.351)\end{array}$ \\
\hline SG & $\begin{array}{l}\text { coeff. } \\
\text { P. }\end{array}$ & & & & & & $\begin{array}{l}0.005 \\
(0.000)^{*}\end{array}$ & & $\begin{array}{l}0.004 \\
(0.000)^{*}\end{array}$ & $\begin{array}{l}0.005 \\
(0.000)^{*}\end{array}$ \\
\hline Adjusted & & -0.004 & 0.061 & 0.094 & -0.004 & -0.004 & 0.081 & 0.095 & 0.152 & 0.150 \\
\hline
\end{tabular}
Model (sample Size: 226)

Symbols $*$ and + represent the significance levels at 1 and $5 \%$, respectively 
American J. Applied Sci., 2 (1): 383-386, 2005

Table 3: The Correlation of a Good Stock (VLTI as a Proxy) with the Various Firm Characteristics in the Fixed Effect Model (Sample Size: 226)

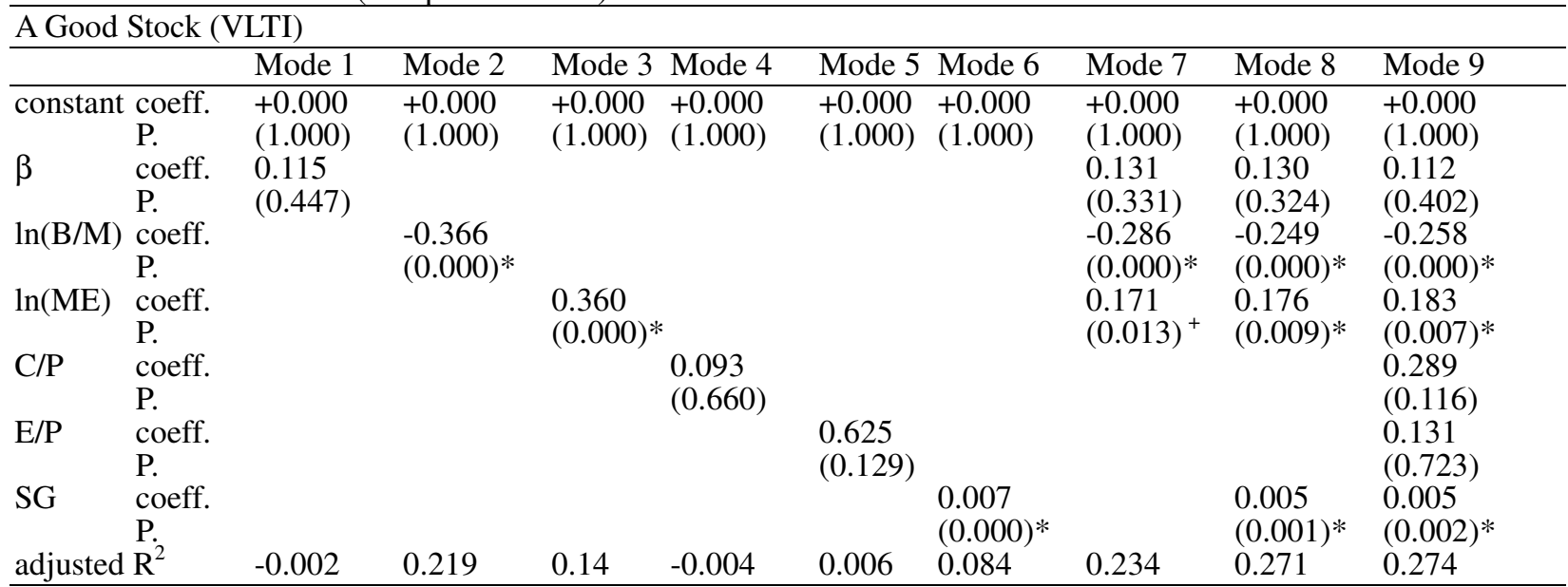

Symbols * and + represent the significance levels at 1 and $5 \%$, respectively

Table 4: The Comparison of the Average Buy-and-old Returns for the Sample Firms with the Matching Firms

\begin{tabular}{lllll}
\hline Buy and hold $\quad$ Sample firms & Size-matched firms & Sample firms & Industry-size matched firms
\end{tabular}

Return (\%)

\begin{tabular}{|c|c|c|c|c|}
\hline Average values & 10.9041 & -4.8203 & 8.2025 & 0.3764 \\
\hline$t$ statistics & & $3.81 * * *$ & & $1.53^{*}$ \\
\hline Pair numbers & & 248 & & 167 \\
\hline
\end{tabular}

Symbols $* * *$ and $* * *$ represent the significance levels at 10,5 and $1 \%$, respectively

where the stock of good companies (AVG as a proxy) and good stocks (VLTI as a proxy) are determined by surveying the financial experts. In this study, the multiple regression method and fixed effect model of panel data are used to test the correlations among these variables.

The cognitive biases hypothesis is proposed in this study. It is assumed that some particular firm characteristics for good companies are probably mistaken for the ones of good stock which are expected to have a higher expectation on stock returns. Under such circumstances, the investors easily neglect other important firm characteristics and expect the firms with these particular characteristics to have a higher stock return. Due to the lack of complete analysis, the cognitive biases and the wrong investing decision are possibly occurred, resulting in the investment loss. This hypothesis, respectively, examines the correlations of the firm characteristics with "stock of a good company" and "good stock". From the results generated in this study, the occurrence of the cognitive biases can be further verified.

To compare the performance of sample firms (good stocks or good companies by the financial experts), the matching firms approach, including the size-matched and industry and size-matched, is used to construct the controlling firms. The criterion of choosing a size-matched firm is to minimize the difference of market equity between the size-matching firm and the sample firm. Usually, the difference is set to be less than $30 \%$. For the industry and size-matched firms, both sample firms and matching firms are in the same industrial category and the difference in the market equity is minimized. After constructing the size-matched and industry / size-matched benchmark, the difference of average buy and hold return between the two groups can be further tested.

\section{RESULTS AND DISCUSSION}

[7] found that the higher expectation of stock return usually has a lower realized stock returns. This is probably because the financial analysts mistake the stocks of good companies for good stocks. However, the previous discussion has also shown that the study [8] provides the opposite evidence. To study whether cognitive biases are occurred in the Taiwan stock market, the correlation of the firm characteristics between good stocks and the stocks of good companies is firstly studied. The data from the annual survey of company 
reputations conducted by the Common Wealth Magazine from 1997 to 2002 are used to investigate the perception of financial experts on good companies and good stocks. The correlation of the perceptions on the good company with the firm characteristics for each year (from 1997 to 2002) is also studied. In addition, the fixed effect model is also used to investigate all the data in six years, as shown in Table 2. Table 2 shows that the calculations from the single-year regression or the fixed effect model regression show the similar results.

The results shown in Table 2 also reveal that the book to market ratio $(\mathrm{B} / \mathrm{M})$, market equity $(\mathrm{ME})$ and sales growth rate $(\mathrm{SG})$ have a significant relationship with AVG, which is a proxy for the good companies. The results calculated from the fixed-effect regression indicate that a company, which has a higher growth opportunity (i.e., lower B/M), a larger firm size, or a higher sales growth rate, is usually considered as a good company by the financial experts.

The perception of financial analysts on the good stocks is also investigated. In this study, the value of long-term investment (VLTI) of each company survey by the Common Wealth Magazine is used as a proxy for a good stock. Similar methodology has been reported in several studies $[6,8]$. The regression results shown in Table 3 imply that the good stocks have the same characteristics as the stocks of good companies. The survey respondents (financial experts) invited by the Common Wealth Magazine consider that good stocks still have the characteristics of a larger firm size, a higher sales growth rate and a lower book-to-market ratio. Therefore, it is concluded from Tables 2-3 that typical Common Wealth Magazine respondents mistake stocks of good companies for good stocks. Thus, the stock of a good company is usually expected to have a good return as a good stock.

The following study will investigate if these stocks of good companies and good stocks do have higher average buy-and-hold returns. For each sample firm, the corresponding matching firm is chosen from the TSEC / OTC stock markets. As shown above, the criterion of choosing a size-matched firm is to minimize the difference of market equity between the size-matched firm and the sample firm and the difference is normally less than $30 \%$. For the industry-size matched firms, both sample firms and matching firms are in the same industrial category and the difference in the market equity is minimized.

Table 4 shows the average one-year buy-and-hold returns for the sample firms and matching firms. The average buy-and-hold return of sample firms is found to be significantly higher than that of matching firms. Furthermore, both differences are, respectively, reached at $1 \%$ and $10 \%$ significant levels. Although the previous results have shown that financial experts mistake the stocks of good companies for the good stocks, sample firms (including good companies and good stocks) do have higher average next-year buy-and-hold return than the matching firms. This evidence is consistent with the finding [8]. Even the results show that the stocks of good companies are mistaken for the good stocks, but the stocks returns for the good companies or stocks are still higher than the matching firms. Thus, it can be concluded that the cognitive biases hypothesis can not be accepted in this study.

\section{CONCLUSION}

This study is aimed to provide the evidence to verify the cognitive biases hypothesis. The surveys for the Taiwan companies from 1997 to 2002 conducted by Common Wealth Magazine are chosen as the proxies of good companies and good stocks. In addition, the corresponding financial information published in the TEJ data base for the listed companies in TSEC and OTC market are also used to verify the proposed hypotheses in this study.

The results generated in this study indicate that the firm characteristics of the stocks of good companies are almost the same as those of good stocks. A company which has a higher growth opportunity (i.e., lower B/M), a larger firm size, or a higher sales growth rate is considered as a good company and a good stock. The empirical results also reveal that those companies considered as good companies or good investments always have the higher stock return than the others. Thus, these empirical results suggest that the cognitive biases hypothesis can not be accepted in this study. This study has shed light on the influence of analysts' perception or behavior on the stock market. The present results can be used to understand the influence of recommendations by financial analysts on the stock market.

\section{ACKNOWLEDGMENT}

The supports from the National Science Council in Taiwan (NSC-92-2626-H228-001 and NSC-93-2626H228-001) are acknowledged.

\section{REFERENCES}

1. Womack, K. L., 1996. Do brokerage analysts' recommendations have investment value? J. Finance, 51:137-167.

2. Hong, H. and J.D. Kubik, 2003. Analyzing the analysts: career concerns and biased earnings forecast. J. Finance, 58: 313-351.

3. Banz, R.W., 1981. The relation between return and market value of Common Stocks. J. Financial Econ., 9: 3-18.

4. Fama, E.F.and K.R. French,1992.The cross-section of expected stock returns. J. Finance, 47: 427-465.

5. Fama, E.F. and K.R. French, 1993. Common risk factors in the returns on stocks and bonds. J. Finance Econ., 33: 3-56.

6. Shefrin, H. and M. Statman, 1995. Making sense of beta, size and book-to-market. J. Portfolio Management, 21: 16-34.

7. Shefrin, H. and M. Statman, 1998. Comparing expectations about stock returns to realized returns. Santa Uara University, (Unpublished Paper).

8. Antunovich and Laster, 1998. Do investors mistake a good company for a good investment? (working paper). 